\title{
Advertising Supplement:
}

\section{Journal of Interamerican Studies and World Affairs}

This supplement has been prepared especially for our readers to bring them information and announcements of professional interest. By placing advertisements in the pages of this journal. our advertisers have indicated a desire 10 communicate with our readers. We hope our readers will acknowledge their indirect support of the journal and its purposes by mentioning the journal in correspondence with advertisers.

\section{COMMUNICATION AND DEVELOPMENT}

\section{adited by Everett M. Rogers}

The disappointing performance of mass communications in fostering development in Latin America has led to alternative conceptions of how to use communication in developing Societies, as well as a redefinition of what development really is. This issue explores these alternatives and examines the implications that new paradigms will have for communication research and training, and for national governments and technical assistance agencies trying to promote development.

CONTENTS: New Perspectives on Communication and Development: Overview (E. M. Rogers) Alien Premises, Objectives, and Methods in Latin American Communication Pesearch (L. R. Beltran S.I Communication of Agricultural Inniovations in Latin America: The Need for New Modeis (J. D. Bordenave) The Diffusion on Innovations and the Issue of Equity in Rural De. velopment (N.G. Roling. J. Ascroft and F. Wa Chege) The Communication Effects Gap: A Field Experiment on Television and Agricultural Ignorance in India (P. M. Shingi and B. Mody) How Does Communication Interface with Change? (G. C. Whiting) Communication and Development:

The Passing of the Dominant Paradigm (E. M. Rogers)

Originally published in Communication Research, April 1976

148 pages / ISBN 0 $8039-0733-8$ / \$3.95
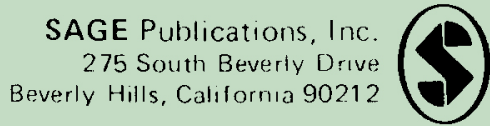

SAGE Publications Ltd

28 Banner Street

!. ondon EC1Y 80 E 


\section{SOCIAL SCIENCE INFORMATION SUR LES SCIENCES SOCIALES}

published under the auspices of the

International Social Science Council, UNESCO, and the Maison des Sciences de l'Homme, Paris

Social Science INFORMATION Sur Les Sciences Sociales, an established international journal now entering its 17 th volume, will be published by Sage Publications commencing with the first issue in 1978.

Social Science INFORMATION provides an international, cross-disciplinary forum for the documentation, analysis and debate of developments in social science research and teaching.

The Journal accepts articles in English and French, with a special focus on the organization and methodology of social science research in a cross-cultural context. Subject areas regularly covered by the Journal include:

Biology and Social Science

Mathematical Anthropology

Computers, Data Systems and

the Social Sciences

Political and Administrative

Demography and Social

Science

Geography

Economics and Planning

Family Sociology

Race Relations

Science Policy Studies

Social and Cultural Anthropology

Social Psychology

International contributors to recent volumes of Social Science

INFORMATION include:
Paul A. Ballonoff
Albert 0 . Hirschman
Raymond Soudon
Seymour Martin Lipset
James D. Coleman
Alain Touraine
S. E. Finer
Albert D. Biderman
Octavio lanni
Manuel Castells
Richard Rose
S. N. Eisenstadt
Robert M. Berdaht
Irving Louis Horowitz
Pierre Bourdieu
Stein Rokkan
Philip E. Converse
Immanuel Wallerstein

Published bimonthly, Social Science INFORMATION (Vol. 17) will appear in February, May, June, August/November (double issue) and December in 1978.

$\begin{array}{clll}\text { Subscription rates: } & \text { One year } & \text { Two years } & \text { Three years } \\ \text { Individual } & \$ 20.00 & \$ 39.00 & \$ 58.00 \\ \text { Institutional } & \$ 40.00 & \$ 79.00 & \$ 118.00\end{array}$

SAGE Publications, Inc. 275 South Beverly Drive Beverly Hills, California 90212

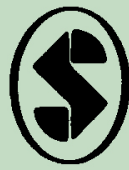

SAGE Publications Ltd 28 Banner Street London EC1Y 80 E 


\section{ECOIDYNAMICS}

\section{A NEW THEORY OF SOCIETAL EVOLUTION}

\section{by KENNETH E. BOULDING}

This book will be compelling reading not only for scholars and students but also for laymen interested in major social issues and the latest comments on these issues by one of the world's most eminent social scientists. This far-reaching exploration of societal evolution tackles some of the toughest philosophical questions facing us today: what is the relationship between physical, biological and societal evolution? are there recurring patterns in the universe and in the social systems man has created? Why do wars occur? To answer these and other questions Boulding has imaginatively synthesized the principles of physical evolution and the tenets and knowledge of all the social sciences into a challenging and important work of ideas. He has written a book which can teach us all a great deal about our contemporary civilization and its future.

CONTENTS: Preface / Introduction / 1. The Universe as a Stereo Movie / 2. Physical Dynamics and Evolution / 3. Population Dynamics / 4. Ecological Dynamics / 5. Biological Evolution / 6. Societal Evolution: The General Pattern / 7. The Threat System / 8. Exchange as a Social Organizer / 9. The Integrative System / 10. An Evolutionary Interpretation of History / 11. Power in Society / 12. Dialectics and Evolution / 13. Evaluative Change / 14. Limits / 15. Evolutionary Dynamics of Religion and Ethics / 16. Alternative /mages of the Future / 17. Alternative Patterns / Glossary / About the Author

\section{About the Author:}

Kenneth E. Boulding is Distinguished Professor of Economics at the University of Colorado and a program director in the University's Institute of Behavioral Science. He is currently President-Elect of the American Association for the Advancement of Science, and has served as President of the American Economic Association and Vice President and President of the International Studies Association.

\section{June 1978350 pages (tent.) ISBN 0-8039-0945-4 hardcover $\$ 15.00$} A Sageview Edition

SAGE PUBLICATIONS, INC. 275 South Beverly Drive Beverly Hills, Calıfornı́ 90212

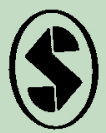

SAGE PUBLICATIONS LTD

28 Banner Street

London ECIY 8QE, England 


\title{
POLITICAL ECONOMY OF THE WORLD-SYSTEM ANNUALS
}

\author{
Immanuel Wallerstein, Series Editor
}

Published in cooperation with the Section on the Political Economy

of the World-System of the American Sociological Association

\section{About the Series}

The intent of this series of annuals is to reflect and inform the intense theoretical and empirical debates about the "political economy of the world-system." These debates assume that the phenomena of the real world cannot be separated into three (or morel categories-political, economic, and social-which can be studied by different methods and in closed spheres. The economy is "institutionally" rooted; the polity is the expression of socioeconomic forces; and "societal" structures are a consequence of politico-economic pressures. The phrase "world-system" also tells us that we believe there is a working social system larger than any state whose operations are themselves a focus of social analysis. How states and parties, firms and classes. status groups and social institutions operate within the framework and constraints of the world-system is precisely what is debated.

These theme-focused annuals will be the outlet for original theoretical and empirical findings of social scientists coming from all the traditional "disciplines." The series will draw upon papers presented at meetings and conferences, as well as invited papers from those who share in these concerns.

Volume 1

\section{Social Change in the Capitalist World Economy} edited by Barbara Hockey Kaplan

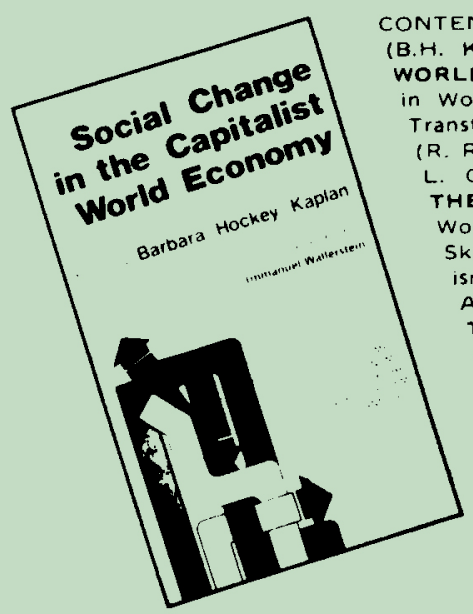
SYSTEM - 1. Marxist Theories of the State World System Analysis ( $F$. Block)/2. Political Wsformation in Germany and the United States (R. Rubinson)/3. Fascism and World Economy (W. Goldrank)/Part Two: REVOLUTION AND THE WORLD SYSTEM - 4. Revolutions and the World-Historical Development of Capitalism (T. Skocpol and E.K. Trimberger)/5. State Capitalism and Counterrevolution in the Middle East: A Thesis (S.K. Farsoun and W.F. Carroll)/Part Three: THE WORLD SYSTEM IN THE 2OTH CENTURY - 6. Core-Periphery Retations: The Effects of Core Competition (C. CaseDunn)/7. Continuity, Change and Tension in Global Capitalism (D. Dowd)/Part Four: WORLD SYSTEM ANALYSIS: Theoretical and Methodological Issues - 8. WorldSystem Analysis: Methodological Issues (T. Hopkins)/9. World-System Analysis: Theoretical and Interpretative Issues (1. Wallerstein)

March 1978 240 pages
ISBN 0-8039-1032-0 ISBN 0.8039-1033-9 hardcover
softcover
$\$ 18.50$

$\$ 7.95$
SAGE Publications, Inc. 275 South Beverly Drive Beverly Hills, California 90212
SAGE Publications Ltd 28 Banner Street London ECIY $80 E$ 


\title{
LATIN AMERICA AND WORLD ECONOMY: A Changing International Order
}

\author{
edited by JOSEPH GRUNWALD
}

How do nations of Latin America interact with other countries in the world community? This anthology approaches the region's relations with the outside world from both an economic and a political perspective, examining Latin America's desire to integrate with the world economy, as well as its struggle for self-reliance. Latin American and non-Latin American contributors discuss a range of subjects including the character of the "special relationship" between Latin America and the United States, and the ambiguous nature of Latin America's relations with other countries of the Third World.

\section{CONTENTS}

Preface by JOSEPH GRUNWALD

1. Overview and Perspective, JOSEPH GRUNWALD

Part I - Economic Relations with Industrial Countries

2. The Mature Neighbor Policy: A Proposal for A United States Economic Policy for Latin America, ALBERT FISHLOW

3. Britain's Economic Relations with Latin America, LAURENCE WHITEHEAD

4. The Economic Relations Between Germany and Latin America and the Significance of the European Community, ALBRECHT von GLEICH

5. Latin America's Opening to the Pacific, CLAUDIO VELIZ

Part II - Mexico and Brazil

6. The External Sector of the Mexican Economy, LEOPOLDO SOLIS

7. The Determinants of Brazil's Foreign Economic Policy, WERNER BAER and CARLOS von DOELLINGER

"As long as the notion persists that Latin America is unimportant for the United States and other developed countries, it will be difficult to persuade Latin American countries that they are living in an interdependent world. One-sided importance creates a one-sided dependency relationship. Such a perseption results in demands, not cooperation. Cooperation for development becomes meaningful only when there is a recognition of interdependence on both sides of the North-South relationship."

- from Chapter 1

Volume 2, Latin American International Affairs

February 1978

ISBN 0-8039-0864-4

320 pages

ISBN 0-8039-0966-7

hardcover

$\$ 18.50$

softcover

$\$ 8.95$

SAGE PUBLICATIONS, INC 275 South Beverly Drive Beverly Hills, Calıforna 90212

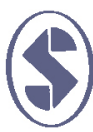

SAGE PUBLICATIONS LTD

28 Banner Street

London EC1Y 8OE. England 


\title{
METROPOLITAN LATIN AMERICA: The Challenge and the Response
}

\author{
Latin American Urban Research, Volume 6 \\ edited by WAYNE A. CORNELIUS, Massachusetts Institute of Technology \\ ROBERT V. KEMPER, Southern Methodist University
}

This volume focuses on the most critical problems confronting nine major Latin American and Caribbean cities, and the actual responses of local and national governments to these problems. Each chapter provides a comprehensive overview of urban development problems and government performance in dealing with them in a single metropolitan area. Contributors also discuss the role of the metropolitan area in regional and national development, and the tensions between government policies aimed at the problems of the metropolitan area and policies for national and regional development. The volume provides indispensible source material for scholars doing research on specific cities as well as an empirical base for comparative urban studies. It also includes a 1,600-item bibliography of studies on urban Latin America published during the 1974-1976 period.

\section{Introduction, WA YNE A. CORNELIUS}

\section{Case Studies}

1. Guadalajara: Creating the Divided City, JOHN WALTON, Northwestern University

2. Mexico City: The Emerging Megalopolis, GUSTAVO GARZA, El Colegio de México and MARTHA SCHTEINGART, El Colegio de México

3. Bogotá: Politics, Planning and the Crisis of Lost Opportunities, ALAN GILBERT, University College, London

4. Urban Development and Governmental Response: The Case of Medell in, DAVID W. DENT, Towson State College

5. Port-au-Prince: Awakening to the Urban Crisis, SIMON M. FASS

6. Urban Problems and Policy Responses for Metropolitan Guayaquil. RICHARD J. MOORE, University of Texas, Austin

7. Metropolitan Lima: Urban Problem-Solving under Military Rule, HENRY A. DIETZ, University of Texas, Austin

8. Caracas: The Politics of Intensifying Primacy, DAVID J. MYERS, Pennsy/vania State University

9. Towards a Development Strategy for Grande Rio de Janeiro, DAVID M. VETTER, Universidade Federal do Rio de Janeiro and ANA MARIA BRASILEIRO. Instituto Brasileiro de Administração

BIBLIOGRAPHY: RECENT URBAN STUDIES ON LATIN AMERICA (1974-1976)

\begin{tabular}{llll}
\hline \hline February 1978 & ISBN 0-8039-0661-7 & hardcover & $\$ 18.50$ \\
352 pages & ISBN 0-8039-0662-5 & softcover & $\$ 7.95$
\end{tabular}

\footnotetext{
SAGE Publications, Inc.

275 South Beverly Drive

Bevesly Hills, California 90212

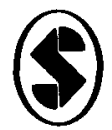

SAGE Publications Ltd

28 Banner Street

London ECTY $80 \mathrm{E}$
} 